\title{
THE AESTHETICISATION OF TASTE, A CONSEQUENCE OF THE "AESTHETICISATION" OF BEAUTY
}

\section{Carole Talon-Hugon}

\begin{abstract}
At the beginning of modern times, taste was seen as a sort of sense of sociability, indistinctly moral and aesthetic. Why, during the eighteenth century did it become exclusively the sense of beauty? To understand this change, this article maintains that we must consider the great revolution, which affected the idea of beauty between the seventeenth and the eighteenth centuries, that is to say the end of the metaphysical conception of beauty. We must analyse the phenomenon of beauty aestheticisation produced by the modern subjectivist, psychological and empirical perspective. The aestheticisation of taste is one of the consequences of the underground ontological revolution, which led to a transformation of the transcendental essences in human values. When beauty is nothing more than beauty, and does not exist without a sensitive experience, one needs a sensitive faculty which enables one to grasp beauty, or more precisely, which gives birth to beauty, seeing beauty as no longer having a proper ontological consistency.
\end{abstract}

KEYWORDS: Taste, Beauty, Disinterestedness, Convertibility of Transcendentals, Modern Scientific Revolution

During the eighteenth century, taste as a sense of beauty was the subject of a great number of essays. It is the topic of Bouhours' Manière de bien penser dans les ouvrages de l'esprit (1668), of Dubos' Réflexions critiques sur la poésie et la peinture (1719), of Hutcheson's An Inquiry into the Origin of Our Ideas of Beauty and Virtue (1725), of Baumgarten's Aesthetica (1750), or, of course, of Kant's Kritik der Urteilskraft (1790). The word “taste” appeared in the very title of numerous books or opuscules, among others Montesquieu's Essai sur le goût (1757), Hume's Of the Standard of Taste (1757), Burke's Introduction on Taste (1759), or Alexander Gerard's Essay on Taste (1759).

For all that, the eighteenth century did not create the figurative sense of the word: this figurative use already existed in Antiquity, for instance in Cicero's or Quintilian's works. Nevertheless, the spread of this figurative use did not occur until modern times. 
From this point of view, Baltazar Gracian is usually regarded as one of the most important authors. He published Oraculo manualy arte de prudencia in Spain in 1647, which was translated into French by Amelot de Houssaie under the title L'homme de cour in 1684. It is true that in this book Gracian uses the word "taste" in a figurative sense. But not yet in the sense of "sense of beauty". The book consists of a whole of maxims formally similar to La Rochefoucault's Maximes, describing good manners, how to behave and to act according to humanist and catholic values in the aristocratic world. L'homme de cour is a guide to good conduct, an art of prudence; it shows how to live honestly and happily at court, avoiding traps and temptations. It deals with questions of reputation, richness, and passions to avoid. What is taste in this context, and what does the word mean? Gracian uses the expression gusto relevante, fine taste, and he defined it as a sort of spiritual discernment. So defined, taste is a sort of capacity, both ethical and aesthetical. This use of the word "taste" bears the marks of the mystical sense the notion had in Bernard de Clairvaux's Sermons sur le Cantique des cantiques or in Ignace de Loyola's Exercices spirituels. For those authors, taste means the power to identify marks of God here on earth. In Gracian, the word still has something of this theological sense, but its signification extends to social life. According to him taste is a sort of tact; so, in Gracian taste was not the sense of beauty it became a century later.

The same remarks concern Shaftesbury's use of the word "taste." According to him, taste is a flair for a good social life. Like politeness, taste stimulates civility, and favours public interest. It cultivates and develops honesty, goodwill, and urbanity. It is a social sense, which plays an important role in the civilisation process, by replacing rudeness and savagery of the past by manners and delicacy.

As we can see, in the seventeenth century and even in the eighteenth century, taste is a sort of sense of sociability, indistinctly moral and aesthetic; it is very close to what we call "tact", and it is not exclusively a sense of beauty.

Then, the question is: why, at a rather precise moment in history, did taste become exclusively the sense of beauty? To understand this change, I maintain that we must consider the great revolution, which affected the idea of beauty beetween the seventeenth and the eighteenth centuries.

\section{A NEW WAY TO CONSIDER BEAUTY}

For us, beauty is usually defined as "what gives rise to an aesthetic experience". That is to say that beauty is conceived as the cause 
of an aesthetic effect, the occasion of a specific pleasure. We can notice the circularity of this definition: beauty is what produces an aesthetic effect, and an aesthetic effect is an effect produced by beauty. We must above all insist on two points: first, beauty is defined by its effects on the subject; secondly, those effects are exclusively aesthetically pleasant. This could appear as a truism. For modern people, it is. But it has not always been the case. Beauty has not always been this narrow aesthetic category it became three centuries ago. What was it before?

\section{THE PRE-MODERN CONCEPTION OF BEAUTY}

The most important characteristic of the pre-modern conception of beauty is to conceive sensitive beauty as depending on a transcendence, and not as an autonomous reality. Sensitive beauty comes from something other than itself; it comes from something higher. So, according to Plato or Plotin, sensitive beauty only exists through its link to the intelligible Idea of beauty, that is to say, to Beauty in oneself, which gives beauty to different things, whilst staying the same. This unique origin explains the relationship between the beautiful things in spite of their individual specificities (a beautiful face, a beautiful tree, a beautiful house...). The idea of beauty printed on man during his celestial existence remains in his soul and allows him to recognize visible beauty and to judge it in comparison to its intelligible model. So, Plato or Plotin did not ignore sensitive beauty, but conceived it as a first step to reach other forms of superior beauties, more noble, more respectable: the beauty of the soul, of virtue, of knowledge, etc. Diotima's speech in The Symposium by Plato describes this ascending process from corporeal beauties to spiritualised forms of beauty, to the very Idea of beauty, that is to say, to non-relational beauty, to absolute, unchanging and eternal beauty.

During the Middle Ages, Christian thinkers went on with this vertical conception of beauty by conceiving beauty as a transcendental property of Being, and more precisely of the supreme Being who is God. God is then the supra-subtantial beauty, and sensitive things are beautiful because they come from him. Aesthetic realities are then theophanic; beauty is indistinct sensitive and metaphysical splendour. This supra-sensitive origin allows to easily conceive notions of "interior beauty", of "spiritual beauty" or of "splendour of the soul": "interior beauty shines brighter than all extrinsic ornaments even brighter than royal jewellery,” wrote St Bernard in one of his sermons. 
This transcendental origin of beauty gives it another important characteristic: its close links to good and truth. The kaloskagatia of ancient Greece closely linked sensitive and spiritual beauty to the good. Christian thought during the Middle Ages considered that beauty does not differ from good nor truth, in the mesure where God is at the same time Beauty, Good and Truth. Those values become mixed up in the supreme Being; they are predicaments of God. They are identical in God and differ only by the manner in which man considers them. As Thomas wrote: "good has a special report to appetite. And for this reason, it could be considered from the point of view of finality; because appetite is, so to speak, a particular impetus towards the thing." ${ }^{1}$ On the other hand, beauty depends on cognitive virtue: indeed, things which are declared beautiful are those which please people when they are observed. The difference between beauty and good only appears from a human point of view: for men, Good is the supreme Being in its conative dimension, beauty is the supreme Being in its perceptual dimension. But in the supreme Being - in God -, they are one; Beauty and Good are equivalent and convertible.

The third characteristic of this ancient conception of beauty results from the preceding two: that is, its objectivity. Saint Augustine's answer to the question: "are things beautiful because they provide pleasure to men, or do they provide pleasure to men because they are beautiful?" is clear: "without any hesitation, I answer: they provide pleasure to men because they are beautiful." 2 Beauty is objective as Good is objective. Neither of them needs man to exist. As Albert le Grand put it, "virtue possesses in itself a brightness, which constitutes its beauty, even if nobody were present to see or appreciate it." ${ }^{3}$ Beautiful things like good things remain beautiful and good, even if the human being is absent. In other words, it is not a subjective agreement that makes them exist. Both exist independently of human perception. Men meet them but do not create them. Beauty is ontologically self-necessary and possesses an objective consistency, which according to Saint Thomas consists in integritas, consonantia and claritas: beautiful is what is without lack, what is well-proportioned and what is radiant.

This metaphysical conception of beauty, with small differences between these authors, remains constant in European culture from Antiquity to the beginning of modern times. Conceiving beauty as the imperfect reflection of the Idea of Beauty (Plato), as triumph of the spirit on the matter (Plotinus), as the emanent ray of the face of God (Christian neo-platonism), in all these cases sensitive beauty is linked to transcendental beauty, objective and absolute, and 
without the latter, sensitive beauty will not exist. So, beauty is not an exclusively aesthetic term and cannot be thought outside of a metaphysics of beauty.

\section{THE MODERN THOUGHT OF BEAUTY}

It is precisely with this understanding of beauty as intelligible reality, moral harmony and metaphysical splendour, that modernity terminates. Contrary to Augustine's answer to the question "are things beautiful because they provide pleasure to men, or do they provide pleasure to men because they are beautiful?" modernity replies that they are beautiful because they provide pleasure.

To understand such a reversal, one must consider a larger revolution, which happened between the sixteenth and the seventeenth centuries, and which deeply affected the way in which the world was considered and understood. Indeed, the new episteme, which appears during the classical age conceives the sensitive world in a radically new way. In short, this sensitive world, made of colorful, ponderous, sonorous, odorous objects became subjective, that is to say that it only exists for a human subject. Partisans of corpuscular mechanical physics (Galilei, Descartes, Boyle, Locke, Newton, etc.) supported that secondary qualities, that is to say qualities we perceive by a single sense (blue, high pitch, bitter, rough...), do not exist in the object. Sugar is in itself neither white nor sweet; whiteness and sweetness do not exist without the sensations. In itself sugar is a mere specific configuration of material particles. The particular sensations felt by the subject happen when his sensorial recepters are in contact with a specific spatial disposition of moving material particles. Objectively only does this microstructure exist. Saying that an object is blue, smooth or perfumed is saying that its molecular structure is so disposed that it in humans causes particular visual or tactile sensations.

This scientific revolution had considerable consequences for the question of beauty. At the beginning, this new understanding of the sensitive world did not affect the question of beauty. It was not until the eighteenth century that the effects of this scientific revolution clearly appeared.

Particularly important for this question was the publication of An Inquiry into the Origin of Our Ideas of Beauty and Virtue by Hutcheson. In Hutcheson's book, we can read the decisive sentence: "in this book beauty is taken as the idea it arouses in us." What does this sentence actually say? That beauty is not an Idea in a platonic sense, but an idea in the modern sense of the word, that is to say a content of the mind, and nothing more than a content of 
the mind. Beauty does not exist without the human subject. It is an idea without capital, and not a real characteristic of some objects in the world. It is only subjective, that is to say that it correlates with a particular mental state and it is nothing outside of that state. In this way Hutcheson wrote, "if no conscious spirit with a sense of beauty exists to contemplate those objects that we say are beautiful, I do not see how we could call them beautiful." 4

Beauty is no longer conceived as a property of the object; even less as an echo in the sensitive things of the eternal Idea of beauty. Beauty is a relational quality, which arises when some objects meet human subjects; it is an idea produced in us through contact with particular corpuscular properties of matter.

Beauty is no longer an essence; beautiful things just exist. Beauty has no more ontological consistency; subjective agreement does not follow it but is formed by it. Montesquieu put it very clearly in his Essai sur le goût : "the ancients [...] considered as positive qualities all the qualities related to our soul; so much so that those dialogues where Plato presented Socrates's reasoning, the dialogues so admired by the ancients, are nowadays indefensible because they are based on a false philosophy: because those reasonings on good, beauty, perfection, rationality, madness, hardness, softness, dryness, dampness, considered as positive things, no longer make sense.” 5

As a consequence of this subjectivisation of beauty, the pre-modern characteristics of beauty vanished: its transcendence, its verticality, its supra-sensitive origin. The question of beauty falls outside ontotheological abilities. The experience of beauty is no longer a metaphysical experience of the world. So, the physico-theological proof of God's existence, which appealed to beauty and to the harmony of the world is no more practicable, as we can see in Hume's Dialogues concerning Natural Religion (1779).

This subjectivisation of beauty also signifies the ending of the convertibility of the Transcendentals. Indeed, when beauty does not have any transcendental origin, it becomes independent of good as well as truth. Hutcheson replaced the objective analogy between beauty and good with a subjective analogy: the one that exists between the sense of beauty and the sense of good, in other words, between two human faculties and two psychological processes of judgment. In 1711, Shaftesbury still wrote in Characteristics: "what is beautiful is harmonious and well-proportioned; what is harmonious and well-proportioned is true; what is at the same time beautiful and true is consequently pleasant and good." 6 In 1715, Crouzat in his Traité du beau, or, in 1719, Dubos in his Réflexions critiques 
sur la poésie et la peinture, still combined beauty and good in the same original nature; but the separation became even more distinct during the eighteenth century. At its end, Kant firmly theorized this separation in the first chapter of his Kritik der Urteilskraft, in isolating the beautiful, the pleasant and the good. Formulas like "a fine action" or "a beautiful soul" are still employed, but the use of the adjective is now metaphorical, or is becoming metaphorical.

So is the double phenomenon of beauty aestheticisation produced by the modern subjectivist, psychological an empirical perspective: beauty is nothing more than beauty, and it does not exist without a sensitive experience.

\section{THE AESTHETICISATION OF TASTE}

The phenomonon of the aesthetisation of beauty enables us to understand both the emergence and the extent of the new notion of taste during the seventeenth and eighteenth centuries.

As we have seen above, until this period taste had an indissolubly ethic and aesthetic signification. Such an intermingling could not survive the end of the objective analogy between beauty and good. Besides, those deep changes affecting the nature of beauty highlighted the question of its perception and its appreciation. Indeed, when beauty is no longer conceived as the sensitive perception of a transcendent Idea or of the divine perfection, in other words, when it becomes aesthetic in a double sense (only relative to beauty and only relative to the sensitive world), by which human faculty could it then be comprehended?

Dubos' book Réflexions critiques sur la poésie et la peinture, published in 1719, is very interesting regarding this issue. Dubos examines the correct way to judge the value of poetic and pictorial works. So, he speaks about artistic achievement and not about natural beauties; nevertheless, what he maintains about the first ones could be applied to the second ones. Being in line with the debate opposing partisans of reason to partisans of feeling, Dubos supported the latter. He maintains that the merits of a poem or a painting are not appreciated by the mind, which evaluates its conformity with the rules of the art of painting or poetry, but by the heart, which directly feels those merits: "Do we reason to know whether the stew is good or bad? Do we ever discuss the proportion of its ingredients after having determined their respective qualities and the geometrical principle of flavour to decide if the stew is good? We never do that. There is in ourselves a sense to know if the cook has made his dishes according to the rules of the art of cooking. We taste the stew, and even without knowing those rules 
we know if it is good. It is also the case with books and paintings that aim to delight in moving us. There is in us a sense designed to judge the merits of those works imitating natural moving objects." 7 Dubos does not call this sense of artistic achievement "taste" but "feeling". However, the analogy he makes between the process of culinary judgment and the process of artistic judgment installs the sensoriality in the aesthetic: the understanding of beauty is the work of a sense.

For all who have adopted the new episteme beauty exists only by the human being. His sense of beauty really has characteristics of taste in a non-figurative sense, in that it supposes a sensitive contact and never decides on beauty without the presence of the object. Like taste in a non-figurative sense, the human sense of beauty decides immediately without the intervention of the intellect. Like the first, the latter never gives up in front of reasons, and its verdict is unwavering. This is what Hutcheson calls its necessity: "no resolution from our part, nor any perspective of an advantage or an inconvenience can change the beauty or the ugliness of an object." 8 No more than I could find bitter the honey, or sweet the lemon, can I find beautiful a house that is only convenient, or ugly the most beautiful of angels when he is Lucifer. In Kantian terms, judgment on beauty cannot be determined by a priori reasons (for example, by the rules of beauty fixed by the Academy), neither by a posteriori reasons (for example, by the concensus of voices). Thoses resemblances explain that the term of taste was retained to design this new sense of beauty.

So, there is a sense of beauty, which has the same name as one of the five senses, but is not one of them. This sixth sense is close to the five senses, but it differs from them by an essential trait: it is an internal sense, without any specific organ, and it decides on the testimony of sight and hearing.

Refusing a role to the understanding in the experience of beauty is the consequence in the subject of the manner to conceive beauty, truth and good in the object. Their unbinding does not signify that beauty and good do not have any relationship: many authors considered the experience of beauty as generating effects in favour of moral tendencies. Thus, Hume argues that beauty soothes the savage impulses to the extent that taste refinement contributes to sociability, to calm passions and to sympathy. Let us also remember that Kant considered beauty as "the symbol of morality." ${ }^{9}$ Even if it is reduced to a sense of mere beauty, taste can be considered as stimulating benevolence and civility, or as a propaedeutics of morality. But those considerations must not mask the radical change, 
which happened in those times: taste became sense of beauty, only sense of beauty and sense of mere beauty. Of course, the development of this sense must be favourable toward morality or sociability, but only indirectly.

The soul needs a specific faculty for beauty, as Sulzer and many others maintained. If, as Hutcheson puts it, we have a sense of beauty and a sense of good that present similarities in their respective processes but which are distinct, we have to designate them by different names. So, the term 'taste' became specialized to designate this 'internal sense' that is the sense of beauty. It is progressively adopted by everybody and became an indispensable philosophical concept. So, in his book Theorie der schönen Künste und Wissenschaften, Just Riedel wrote "Man has three finalities on which his spiritual perfection is founded: Truth, Good and Beauty; for each of them nature gave him a particular faculty: for truth, common sense, for good, conscience, and for beauty, taste." 10

Thus, while in the sixteenth century taste was not yet an aesthectic category, it became progressively the sense of beauty during the eighteenth century and occupied the front of the theoretical stage. So much so that the new discipline we call "aesthetics" is designed by Kant by the expression of "critique of taste". This aestheticisation of taste is one of the consequences of the underground ontological revolution, which led to transform the transcendental essences into human values, and to the unbinding of beauty, truth and good which followed. For this beauty which is only for man and which is only beauty, it needs a non-intelligible but sensitive faculty: a sense, a sixth sense, without specific organ, but which possesses the same characteristics as the five senses: naturality, universality, immediacy, and assurance of its verdict.

The invention of taste is the consequence of the aestheticisation of beauty. In this context, taste is not only the faculty which enables us to grasp beauty: it is the faculty that gives birth to beauty, seeing beauty as no longer having a proper ontological consistency. This is the reason why the notion of taste became so important: the enquiry could no longer focus on beauty or on beautiful things, but had to focus on subjective affections by which, and only by which, beauty exists. Kant's Critique of Judgement is, in this regard, remarkable: here, the enquiry on beauty became an enquiry on taste judgment. An anthropology of the aesthetic experience replaced the metaphysics of beauty. In the first paragraph of his book Kant wrote "only Germans use the word 'aesthectics' to designate what others called critique of taste." 
The new conception of beauty and the new definition of taste which follows explain in their turn the first appearance of other concepts. This is the case with the notion of disinterestedness. Actually, the notion of disinterestedness is only understandable in connection with taste.

Why? As we have seen in paragraph 33 of the Critique of Judgement, taste can oppose an individual preference with collective norms of judgment. That is to say that taste becomes subjective not only in that it only exists for a subject, but also in that it can oppose an individual to his community. However, eighteenth century authors speak about taste and not about tastes, and considers taste as something that makes humans come closer to each other and not as something that splits them. So, Burke maintains in his A Philosophical Enquiry into the Origin of Our Ideas of the Sublime and Beautiful (1757), that taste has "fixed principles" and responds to "sure and invariable rules". In other words, taste, as the other senses, is identical in every man. Consequently, how to reconcile the claim of the naturality - and thus of the universality - of taste, and the observation of the variety of tastes?

The eighteenth-century authors answer first that the variety of appreciations concerning beauty can be explained by physiological differences between humans. A colour-blind person sees as green things that other people see as red because of a deficiency in the colour sensing cones of his or her eyes. If somebody hears a sound that someone else does not hear, it is because the hearing of the first is better. As we can have a more or less piercing sight, a more or less sharp hearing or a more or less refined palate (like Sancho Panza's parents, in the episode of Don Quixote quoted by Hume in his "Of the Standard of Taste"), we can have a sense of beauty that is more or less naturally developed. But this is not the only reason for the differences in appreciations concerning beauty. Divergences can also come from different forms of personal interest combined with aesthetic appreciation. In this case, taste judgment becomes impure.

Because beauty is independent of other values as utility, convenience, or truth, we must avoid bringing into play extra aesthetic values. Thus, Hutcheson carefully distinguishes the pleasure of beauty from "the joy generated by the prospect of advantages." 11 Regardless of the prospect of an advantage or of a disadvantage for us, we cannot find an ugly object beautiful, or a beautiful object ugly. Even if we know the good properties of a bitter medicine we cannot sense it as sweet. Of course, as Hutcheson puts it, the pleasant prospect of a relief joined with the present pain could 
give the ingestion of this bitter medicine an overall positive valency; but this positivity comes from the idea of relief and not from the mere sensation.

Kant's Critique of Judgement also insists on the necessary distinction between different sorts of satisfaction. The satisfaction that is produced by beauty is not the one that is produced by good: beauty delights, but good is esteemed. ${ }^{12}$ So appeared the new notion of disinterestedness. Considering goodness or utility of an object supposes that we are interested in the existence of this object. Because beauty has been unbound from good, the experience of the first must be distinguished from the experience of the latter.

Thus, the judgment of taste must be disinterested. It does not signify of course that we do not have any interest in the object considered, but that we do not have any extra-aesthetic interest in it. In other words, we must exclude personal interests (convenience, advantages, memories, etc.), as well as human interests (intellectual, political, ethical, etc.). Because the autonomy of beauty demands the autonomy of taste, disinterestedness became a new crucial concept.

\section{CONCLUSION}

The scientific revolution, which promoted a mechanical-corpuscular conception of matter, seemed very far from aesthetics and the philosophy of art. Nevertheless, I maintain that it is this scientific revolution that explains the appearance and the pregnancy of the concept of taste in the eighteenth century. It is the aestheticisation of beauty that explains the aestheticisation of taste, and consequently, the appearance of the new idea of disinterrestedness. The aestheticisation of beauty also impacted on the new category of fine arts. Indeed, in considering beauty - from now on isolated from good and truth - as the main aim of art, the eighteenth century achieved the aestheticisation of art. But this subject oversteps my present topic. I will just underline the underground links that join all these conceptual innovations: taste, disinterrestedness, fine arts, and also genius and public. This new notional plan is linked to new institutions (for example the Salons) and new disciplines (Art criticism, Art history and Aesthetics). So, the modern paradigm of art was established out of a nebula composed of classificatory categories, of beliefs about its aims, about the uses and values of its objects, of manners of conceiving their producers, their addressees, the places where the art works are exhibited, the institutions where they are produced, etc. 
The conceptual categories that are so attacked by contemporary art today, but which are still ours, thus originate from the very complex but very consistent paradigm that took shape during the Enlightenment.

\section{NOTES}

1 St Thomas, Somme théologique, XIIIth c., Prima pars, question 11.

2 St Augustin, De vera religione, 390, chap. 32.

3 St Albert the Great, Commentary on the Divine Names, XIIIth c., Chapter 4: De Pulchro et Bono.

4 Francis Hutcheson, An Inquiry into the Origin of Our Ideas of Beauty and Virtue, 1725, I, I, 16.

5 Charles-Louis Montesquieu, Essai sur le goût, 1757.

6 A. A. C. Shaftesbury, Characteristics, 1711, III.

7 J.-B. Dubos, Réflexions critiques sur la poésie et la peinture, 1719.

8 Hutcheson, op. cit., I, 1, 13.

9 Immanuel Kant, Critique of Judgement, 1790, § 59.

10 Friedrich Justus Riedel, Theorie der schönen Künste und Wissenschaften, 1767.

11 Hutcheson, op. cit., I, I, § XIV.

12 Kant, op. cit., § 5. 